\title{
Aiduti in Japanese Multi-party Design Conversations
}

\author{
Yasuhiro Katagiri \\ Future University - Hakodate \\ 116-2 Kameda-Nakano Hakodate Hokkaido, Japan \\ katagiri@fun.ac.jp
}

\begin{abstract}
Japanese backchannel utterances, aizuti, in a multi-party design conversation were examined, and aizuti functions were analyzed in comparison with its functions in twoparty dialogues. In addition to the two major functions, signaling acknowledgment and turn-management, it was argued that aizuti in multi-party conversations are involved in joint construction of design plans through management of the floor structure, and display of participants' readiness to engage in collaborative elaboration of jointly constructed proposals.
\end{abstract}

\section{Introduction}

Backchannel utterances are one of the representative phenomena characterizing conversational interactions. We can find backchannel utterances in every natural conversation in every culture. Different languages have different repertoire of expressions that work as backchannels. In terms of what functions they serve in conversations, it has widely been acknowledged that backchannels, by conveying the hearer feedback to the speaker, serve to contribute to informational coordination between conversational participants, through conversational flow management in terms of both common grounding and smooth turn-taking. It has also been acknowledged, perhaps less explicitly, that backchannels serve to contribute to affective coordination by promoting rapport between conversational participants. It is still unclear how these two contrasting views on backchannels can be integrated. How are the informational and the affective coordination functions of backchannels inter-related? What factors determine relative salience of these two functions in certain usage of backchannels? Are there any categories of conversational interactions that promote one or the other functions? Are there cultural differences in backchannel usages?

We focus, in this paper, on the use of Japanese backchannels, aiduti, in multi-party conversations. Based on the analysis of how aiduti utterances are employed in experimentally captured multi-party design conversation data, we argue that aiduti utterances in Japanese have, on top of the informational coordination functions of common-grounding and turn-management, the function of expressing the readiness, a positive attitude, on the part of a participant to engage in the joint construction of an ongoing proposal currently under discussion, which then leads to affective coordination.

\section{Backchannels in Dialogues}

Backchannel utterances were conceived initially in two-party dialogues with one speaker and one hearer. Schegloff (1982) picked up hearer's short utterances such as 'uh, huh' produced in response to the speaker's main utterances, and characterized them as backchannels, whose functions are to convey backward messages from the hearer to the speaker indicating that the hearer is attending to, listening to, understanding, and expecting to continue the production of the speaker's main message.

Heritage (2006) provides a broader conception of backchannels and lists the following four functions 


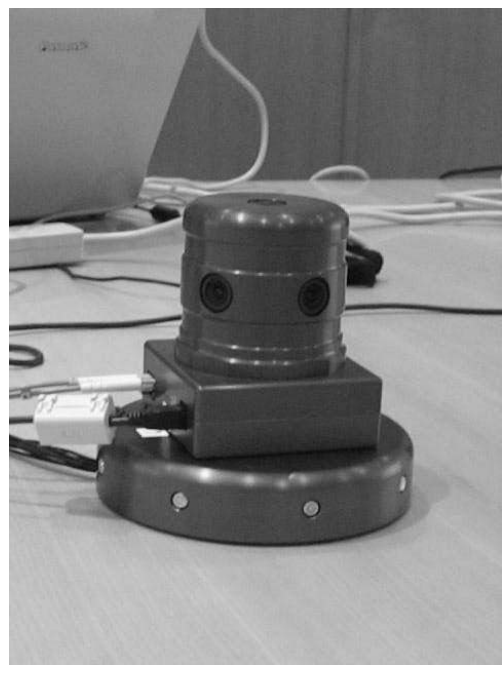

Figure 1: Meeting archiver equipment MARC used in data collection

for backchannel utterances.

- Provide Acknowledgments to prior locutions by the speaker

- Projection of further talk in turn taking

- Recipient epistemic states triggered by the speaker's message

- Recipient affiliative attitude, how the recipient is aligned with speaker's message

Maynard (1986) compared Japanese and American dialogues, and observed that Japanese dialogues have almost twice as much aizuti as American backchannel utterances. This observation suggests that significance of backchannels and their functions in conversational interactions may depend on social groups, types of activities and other social or task related parameters.

\section{Multi-party Conversation}

\subsection{Varieties of multi-party conversations}

We will focus on aiduti utterances in Japanese multiparty design conversations. In order to locate the type of activity we've been working on within the broad range of interaction activities collectively categorized as multi-party conversations, we first try to list up potential parameters that might influence the

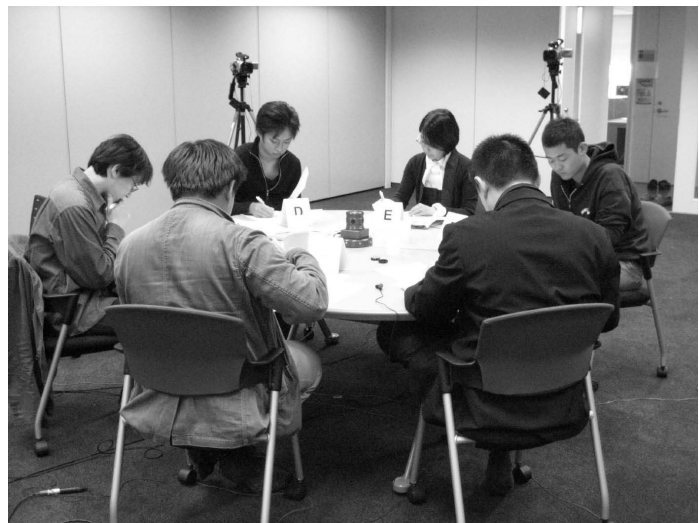

Figure 2: Setting for multi-party design conversation capture

structure and organization of conversational interactions.

\section{Number of participants}

We call a conversation between more than two people a multi-party conversation. A conversation between three people and a conversation between 10 people are not the same in their conversational organization. It has been observed (Fay et al., 2000) that conversations with a small number of participants tend to be homogeneous that contain a number of equal status pairwise interactions, whereas conversations with a large number of participants tend to be more hierarchical with a central control person working as a chairperson.

\section{Types of activities}

Conversational interactions are often embedded in larger activities, and the type of embedding activities makes a difference in the organization of conversations.

\section{(a) Purpose}

One-way information transfer in lectures and joint problem solving in a group of people have both fixed but different types of goals. When people chat for socialization, having a conversation itself becomes its own purpose. These different types of goals could produce different organizational structures in conversations.

(b) Rigidity of purpose

Even within joint problem solving activities, 


\begin{tabular}{|c|c|c|c|}
\hline Sp & Utterance & $\mathrm{Sp}$ & Utterance \\
\hline D: & 普段 & B: & う (un) \\
\hline D: & 光の携帯会社変えないにしても使ってて & $\mathrm{C}:$ & ていうかお年寄りというか (D_バ) 僕の親 \\
\hline D: & メールアドレスが:光のもう 1 個持てたら & $\mathrm{C}:$ & (laugh) \\
\hline & $\begin{array}{l}\text { (I often think that even when you keep using the } \\
\text { same mobile carrier, if you could have one more } \\
\text { mail address,) }\end{array}$ & $\mathrm{C}:$ & などとですねメールをやり取りしようとすると \\
\hline E: & うんうんうん (un-un-un) & & $\begin{array}{l}\text { (when I try to correspond by mail with elderly, eh, } \\
\text { with my parents) }\end{array}$ \\
\hline D: & $\begin{array}{l}\text { いいなあとか } \\
\text { (it would be nice) }\end{array}$ & $\begin{array}{l}\mathrm{E}: \\
\mathrm{B}:\end{array}$ & $\begin{array}{l}\text { ううん (un-un) } \\
\text { う (un) }\end{array}$ \\
\hline D: & パソコンだったらいくらでも & $\mathrm{E}:$ & j (un) \\
\hline & (with $\mathrm{PC}$, any number of addresses) & $\mathrm{C}:$ & まあ親は:打てないんです:よね \\
\hline F: & うんうん (un-un) & & (parents cannot type) \\
\hline E: & ああ:あはいはいはいはい (aa-aa, hai-hai-hai-hai) & B: & う (un) \\
\hline D: & $\begin{array}{l}\text { 持てるじゃないですか } \\
\text { (you can have) }\end{array}$ & $\begin{array}{l}\mathrm{E}: \\
\mathrm{C}:\end{array}$ & $\begin{array}{l}\text { うん (un) } \\
\text { でも通話はできる }\end{array}$ \\
\hline F: & $\left(D_{-} ノ-\right)$ & & (but, they can talk on the phone) \\
\hline B: & う (un): & B: & うん (un) \\
\hline C: & う (un) & $\mathrm{E}:$ & うんうん (un-un) \\
\hline $\begin{array}{l}\text { D: } \\
\text { E: }\end{array}$ & $\begin{array}{l}\text { あ兴ういうのは } \\
\text { う (un) }\end{array}$ & $\mathrm{C}:$ & $\begin{array}{l}\text { でもあの:やり取りできればメールでやりたいと } \\
\text { (but, when you'd rather want to use mails, if possi- } \\
\text { ble) }\end{array}$ \\
\hline D: & $\begin{array}{l}\text { 欲しいなと思いますよ } \\
\text { (I would definitely want one) }\end{array}$ & $\begin{array}{l}\text { E: } \\
\text { B: }\end{array}$ & $\begin{array}{l}j ん う ん う ん \text { (un-un-un) } \\
\text { j (un) }\end{array}$ \\
\hline B: & うん (un): & $\mathrm{C}:$ & いう場合 \\
\hline E: & (D_ンドー) & $\mathrm{F}:$ & うん (un) \\
\hline E: & メルアドを複数ってことですよね & C: & $\begin{array}{l}\text { 例えば: } \\
\text { 立声訒新で. }\end{array}$ \\
\hline D: & $\begin{array}{l}\text { (You mean, multiple mail addresses, right?) } \\
\text { はい (hai) }\end{array}$ & C: & $\begin{array}{l}\text { 音声認識で: } \\
\text { (how about, with speech recognition) }\end{array}$ \\
\hline C: & うん (un): & $\mathrm{E}:$ & ああ (aa) いいですね: \\
\hline C: & まあお年寄り向けの & & (that's good) \\
\hline & (for elderly people) & $\mathrm{B}:$ & j h (un): \\
\hline E: & うんうん (un-un) & $\mathrm{C}:$ & 文章んなっ \\
\hline C: & あの: & & (convert speech into text) \\
\hline
\end{tabular}

Figure 3: Aiduti in design conversation

we can conceive of different degree of rigidity of problem goals conversational participants are working on. In one extreme lies a pursuit of a fixed goal such as mathematical problem solving, in which a problem with a clearly determined answer is given to the group. In other extreme lies a problem solving under a loosely stated goal such as floor planning of an apartment for the group, in which the only requirement is to reach an agreement, and factors to consider must be made explicit in the course of conversation. The design conversation we've looked at belong to the latter category.

\section{(c) Reality}

Every experimental data collection has to face this problem. Whether or not and how much the outcome of the conversation has real import in participants' life makes a big difference in conversational organization.

(d) Use of objects

Use of physical objects, particularly informational artifact such as whiteboard and projectors, changes the use pattern of multi-modal signals: gaze, gestures and body postures, and needs to be taken into account in experimental data collection.

\section{Characteristics of participants}

(a) Participant properties

Differences in capabilities such as in knowledge and in expertise, and dispositional properties, such as preferences, beliefs, and personalities of participants greatly contribute to shape the interaction.

(b) Participant roles 


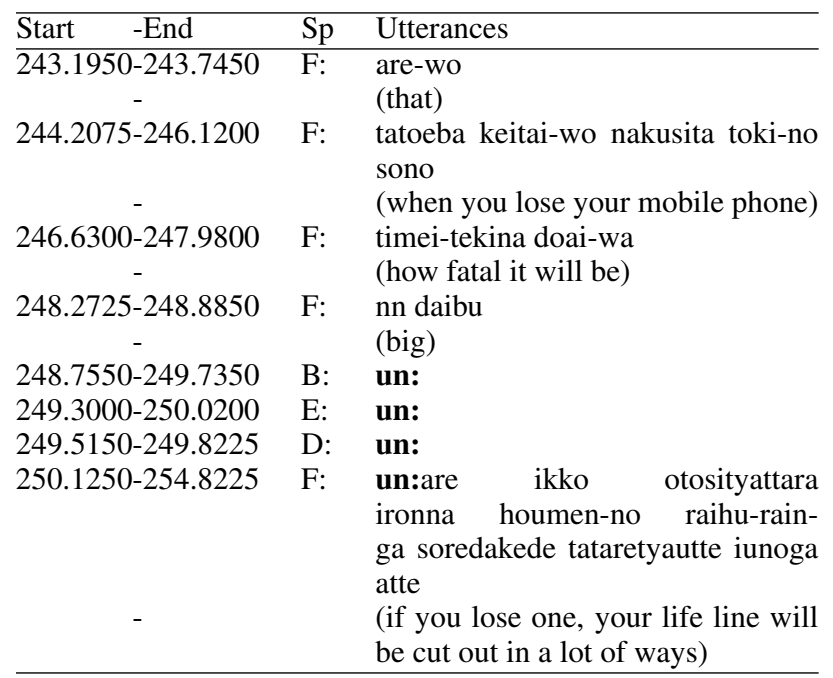

Figure 4: Aiduti overlap

Conversation setting often dictates certain role assignment to each participant, which in turn determines the shape of interactions that takes place between people under those participant roles. Instructor and follower in instruction giving tasks, and clerk and customer in commercial transactions are typical examples. The role of chairperson also is significant in determining the structure of conversations.

(c) Participant relationships

Age and social status often provide a fixed base for dominance relationship among conversational participants. Affiliative familiarity between participants are less fixed but still stable relationships. Sharing of opinions is temporary and can change quite quickly during the course of a conversation.

\subsection{Multi-party design conversation}

We have been collecting data on multi-party design conversation in Japanese. Multi-party design conversation is a type of joint problem solving conversation, in which participants engage in a discussion to come up with an agreement on the final design plan. The design goal, however, is only partially specified, and participants need to jointly decide on evaluative criteria for the design goal during the course of the discussion.

\begin{tabular}{|c|c|c|}
\hline -End & $\mathrm{Sp}$ & Utterance \\
\hline $781.5050-781.6100$ & C: & あ \\
\hline $\begin{array}{c}781.7750-782.7050 \\
-\end{array}$ & C: & $\begin{array}{l}\text { じゃもう } 1 \text { つちょつとあの } \\
\text { (one more thing) }\end{array}$ \\
\hline 782.6300-782.8900 & E: & はい \\
\hline $782.9550-784.4925$ & C: & $\begin{array}{l}\text { あのコミニケーション関係で } \\
\text { (related to communication) }\end{array}$ \\
\hline 784.6050-784.7750 & E: & $j h$ \\
\hline 784.6500-786.6450 & $\mathrm{C}:$ & $\begin{array}{l}\text { ちょつとだけあの思いつきなんで } \\
\text { すけど: }\end{array}$ \\
\hline $\begin{array}{l}- \\
786.1925-786.6950\end{array}$ & & (just a thought) \\
\hline $\begin{array}{l}86.1925-786.6950 \\
787.3475-788.4875\end{array}$ & E: & うんうん \\
\hline $87.3475-788.4875$ & C: & あの:まメールとか: \\
\hline $8.6125-789.9975$ & C: & あのやり取りするときとか: \\
\hline $90.5375-790.6175$ & C: & （W_ト一特に） \\
\hline 790.7975-792.2575 & C: & 特にま携帯メールとかだと \\
\hline 792.6125-795.7250 & $\mathrm{C}:$ & $\begin{array}{l}\text { ま結構あのパソコンメールと違っ } \\
\text { て早めの返事を } \\
\text { (when you exchange mails, particu- } \\
\text { larly on mobile phones, people ex- } \\
\text { pect quicker responses) }\end{array}$ \\
\hline $830.4175-831.7750$ & C: & まそんなようなのがわかると \\
\hline $831.7125-832.0400$ & B: & え: \\
\hline $832.1475-833.1475$ & E: & あ: \\
\hline $832.3675-833.3750$ & C: & まいいかな:みたいな \\
\hline $\begin{array}{c}832.3875-834.4525 \\
-\end{array}$ & B: & $\begin{array}{l}\text { ドライブモードのなんか } \\
\text { (drive mode) }\end{array}$ \\
\hline $834.4450-835.5700$ & E: & あ:ん \\
\hline $834.6325-834.9900$ & $\mathrm{C}:$ & ええ \\
\hline $\begin{array}{c}834.8000-836.3450 \\
-\end{array}$ & B: & $\begin{array}{l}\text { 携帯版みたいな感じで } \\
\text { (on the mobile phone) }\end{array}$ \\
\hline $\begin{array}{c}836.0075-837.5475 \\
-\end{array}$ & C: & $\begin{array}{l}\text { ええああドライブモードってある } \\
\text { (Ah, I know drive mode) }\end{array}$ \\
\hline $837.4525-842.8250$ & B: & $\begin{array}{l}\text { (W_エントーえーと) なんかこう } \\
\text { 今運転中ですみたいなのがこう電 } \\
\text { 話すると出るのと同じで } \\
\text { (same as, when you make a call, it } \\
\text { says it's on drive now) }\end{array}$ \\
\hline - & & \\
\hline $\begin{array}{c}844.8375-846.2475 \\
-\end{array}$ & B: & $\begin{array}{l}\text { 方いううの゙返ってくる } \\
\text { (you get those responses) }\end{array}$ \\
\hline $\begin{array}{c}845.1450-846.6375 \\
-\end{array}$ & E: & $\begin{array}{l}\text { 結構簡単にでき乥うですよね } \\
\text { (it seems rather simple to realize) }\end{array}$ \\
\hline $846.2325-846.3950$ & $\mathrm{C}:$ & うん \\
\hline $846.5650-846.7850$ & C: & jh \\
\hline $846.5750-848.2600$ & D: & $\begin{array}{l}\text { あのヤフーメッセンジャーってあ } \\
\text { るじゃないですか } \\
\text { (you know Yahoo messenger?) }\end{array}$ \\
\hline $847.5825-847.8575$ & B: & 咳 \\
\hline $847.9050-848.5125$ & E: & うん: \\
\hline $848.1400-848.6200$ & B: & $j h:$ \\
\hline $848.4450-849.5650$ & D: & あれ使ってると:兴の \\
\hline $\begin{array}{c}849.9125-851.3250 \\
-\end{array}$ & D: & $\begin{array}{l}\text { メッセンジャーの相手の状況が } \\
\text { (you can see the situation of your } \\
\text { correspondent) }\end{array}$ \\
\hline $851.3600-851.8900$ & E: & jh: \\
\hline
\end{tabular}

Figure 5: Floor structure 


\begin{tabular}{crr}
\hline \hline Speaker & Utterance & Aiduti \\
\hline A & 158 & 3 \\
B & 426 & 179 \\
C & 420 & 125 \\
D & 346 & 138 \\
E & 612 & 343 \\
F & 206 & 69 \\
\hline Total & 2,168 & 857 \\
\hline \hline
\end{tabular}

Table 1: Number of utterances and aiduti produced in multi-party design conversation

\begin{tabular}{lll}
\hline Japanese form & sound & translation \\
\hline はい & hai & (yes) \\
うん & un & (yeah) \\
ああ & aa & (ah) \\
ええ & ee & (correct) \\
そう & sou & (I agree) \\
\hline
\end{tabular}

Table 2: Linguistic forms of aiduti

The condition of our data collection was as follows:

Number of participants: six for each session

Arrangement: face-to-face conversation

Task: Proposal for a new mobile phone business

Role: No pre-determined role was imposed

In order to minimize the intimidating effect of a huge recording setup, we used a compact meeting archiver equipment, MARC, currently under development in AIST Japan (Asano and Ogata, 2006) shown in Fig. 1. MARC is equipped with an array of 6 cameras together with an array of $8 \mathrm{mi}-$ crophones, and it captures panoramic video with up to 15 frames/sec. and speaker-separated speech streams with $16 \mathrm{kHz}$ sampling rate. A meeting capture scene is shown in Fig. 2.

The data we examine in this paper consists of one 30 minutes conversation conducted by 5 males and 1 female. Even though we did not assign any roles, a chairperson and a clerk were spontaneously elected by the participants at the beginning of the session.

\section{Aizuti in multi-party design conversation}

\subsection{Aiduti types and amounts}

We first looked at how frequent people produce aiduti in the conversation. Table 1 shows the number of utterances and aiduti utterances for each of the six speakers, both in terms of the number of inter-pausal units (IPUs). Table 2 indicates expressions identified as aiduti utterances. Positive responses to questions and requests are not included in aiduti, even if they share the surface forms of Table 2. Reduplicated forms of each of the aiduti expressions in Table 2 are also frequently observed, and they were counted as one aiduti occurences.

We can see that a sizable portion of utterances, about $30 \%$ to $40 \%$, were actually aiduti utterances in our data. An example excerpt demonstrating the abundance of aiduti is shown in Fig. 3, where aiduti utterances are marked by bold characters.

\subsection{Conversation flow management}

\section{Overlapping aiduti}

One reason why multi-party conversation contains a lot of aiduti is that there are more hearers, potential backchannel producers. Fig. 4 shows an example in which three hearers B,E, and D produced aiduti almost simultaneously to the speaker F's utterance. The fact that these three aiduti were overlapping shows that they are independently directed to the speaker F's preceding utterance. This type of aiduti response is expected to increase in numbers as the number of conversation participants increases.

\section{Aiduti for turn-holding}

In the same example in Fig. 4, the speaker F produced aiduti 'un' after all aiduti utterances by hearers B, E, and D, and immediately before he continued his turn. This type of speaker aiduti can be taken to serve the turn-holding function. It gives an acknowledgment to all the acknowledgments from hearers collectively and signals that the speaker is going on producing his own message.

\section{Aiduti for floor transition}

A relatively clear structure was observed in the conversation we analyzed. The conversation consisted of a sequence of idea proposals produced by 


\begin{tabular}{lr}
\hline \hline Aiduti $\rightarrow$ Floor & Num \\
\hline Aiduti speaker becomes the next floor main speaker & 53 \\
non-Aiduti speaker becomes next floor main speaker & 17 \\
\hline Total & 70 \\
\hline \hline
\end{tabular}

Table 3: Aiduti and floor transition

different speakers. We identified a stretch of conversation as a floor in which one main speaker makes a proposal on his or her ideas. As long as the specific proposal is being discussed as the conversation topic, other participants may contribute clarification or elaboration utterances within the same floor. An example of a sequence of floors is shown in Fig. 5. $\mathrm{C}$ first talks about the difference in people's expected response between mobile mails and PC mails in the first floor. B then brings about in the second floor a suggestion on some functionality similar to drive mode which indicates to the original sender that the recipient is not available at the moment. D in the third floor follows on by mentioning Yahoo messenger. We extracted 71 floors total from the 30 minute conversation data.

Table 3 indicates the relationship between the production of aiduti in one floor and the claiming of the main speaker-hood in the next floor. The table shows that many of the main speaker of a floor had produced aiduti as a non-main speaker in the preceding floor. This suggests that aiduti utterances from non-main speakers indicate their readiness to make a positive contribution to the joint task, by taking the next floor and by contributing a proposal for the task when they find a suitable opportunity.

\subsection{Collaborative elaboration of proposals}

When we take a closer look into floors, we find positive collaborative behaviors from non-main speaker participants. Typical behaviors of non-main speaker participants of a floor include giving aiduti, providing (positive) evaluations to the idea proposed, and inserting clarification questions. On top of these behaviors, it was often observed in a floor that non-main speaker participants try to make positive contributions to the idea currently on the table, by adding new elements of ideas or providing concrete ideas to part of the proposal that heretofore remained vague at the time. We call these behaviors on the

\begin{tabular}{|c|c|c|}
\hline -End & $\mathrm{Sp}$ & Utterance \\
\hline $\begin{array}{c}505.2500-506.4500 \\
-\end{array}$ & D: & $\begin{array}{l}\text { イメージとしては光の } \\
\text { (as an image) }\end{array}$ \\
\hline $505.4375-505.7225$ & $\mathrm{E}:$ & でも \\
\hline $506.8000-508.1450$ & D: & $\begin{array}{l}\text { (W_サ—3 ) } 3 \text { 年後って書いてありま } \\
\text { すけど光の }\end{array}$ \\
\hline- & & (this says three years from now) \\
\hline $508.6675-509.3500$ & D: & P C と \\
\hline $509.4875-509.9375$ & E: & j \\
\hline $509.5300-510.1400$ & D: & スカイプ \\
\hline $510.3875-510.9250$ & E: & うんうん \\
\hline $510.4875-511.1200$ & B: & あ: \\
\hline $510.5100-510.6650$ & D: & が \\
\hline $510.9125-511.5975$ & D: & くつついたような \\
\hline $511.8375-512.2125$ & E: & jh \\
\hline $512.0075-512.1975$ & B: & はい \\
\hline $512.1125-512.8725$ & D: & 感じだとすごい \\
\hline $512.2650-512.8800$ & $\mathrm{C}:$ & あ: \\
\hline $12.6075-513.2850$ & B: & あ: \\
\hline $\begin{array}{c}513.0050-514.0925 \\
-\end{array}$ & D: & $\begin{array}{l}\text { 便利だな:と思うんですけどね } \\
\text { (it would be really convenient to com- } \\
\text { bine PC with Skype) }\end{array}$ \\
\hline $513.3875-514.2525$ & E: & jん \\
\hline $\begin{array}{c}513.6325-514.1650 \\
-\end{array}$ & C: & $\begin{array}{l}\text { いいですね } \\
\text { (good) }\end{array}$ \\
\hline $\begin{array}{c}514.3150-515.2350 \\
-\end{array}$ & $\mathrm{C}:$ & $\begin{array}{l}\text { スカイプ:で } \\
\text { (with Skype) }\end{array}$ \\
\hline $514.3725-515.5525$ & E: & jh \\
\hline $\begin{array}{c}514.5375-515.3200 \\
-\end{array}$ & B: & $\begin{array}{l}\text { いいっすね: } \\
\text { (good) }\end{array}$ \\
\hline $515.8950-516.0875$ & $\mathrm{C}:$ & やり \\
\hline $516.2775-516.4825$ & $\mathrm{C}:$ & ただ \\
\hline $\begin{array}{c}516.8400-517.8825 \\
-\end{array}$ & C: & $\begin{array}{l}\text { ただ通話し 放題 } \\
\text { (you can call free) }\end{array}$ \\
\hline $\begin{array}{c}517.8100-518.8125 \\
-\end{array}$ & B: & 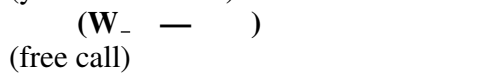 \\
\hline $518.2200-520.8650$ & D: & $\begin{array}{l}\text { ただ通話しま炎のまあ電波の問題と } \\
\text { かも解消して }\end{array}$ \\
\hline - & & $\begin{array}{l}\text { (frequency assignment problem will } \\
\text { somehow be solved) }\end{array}$ \\
\hline $18.2500-519.0475$ & $\mathrm{C}:$ & 笑 \\
\hline $519.0500-519.9925$ & B: & 笑 \\
\hline $519.5150-520.6675$ & $\mathrm{C}:$ & 笑 \\
\hline $520.4400-521.6825$ & E: & うんうんうんうんうん \\
\hline $520.6800-521.3675$ & B: & 笑 \\
\hline $521.5100-522.3050$ & B: & jん \\
\hline $521.8250-522.7875$ & $\mathrm{E}:$ & $j h$ \\
\hline $\begin{array}{c}521.9025-522.9375 \\
-\end{array}$ & D: & $\begin{array}{l}\text { 国際的に使えれば } \\
\text { (if its available worldwide) }\end{array}$ \\
\hline $522.7975-523.0550$ & $\mathrm{C}:$ & ええ \\
\hline
\end{tabular}

Figure 6: Collaborative elaboration: Success 


\begin{tabular}{|c|c|c|}
\hline Start & $\mathrm{Sp}$ & Utterance \\
\hline $543.1750-544.3800$ & $\mathrm{C}:$ & まあ今今:のなんか \\
\hline $544.6725-548.2050$ & $\mathrm{C}:$ & 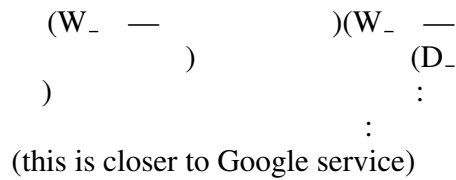 \\
\hline $546.8350-547.5825$ & E: & jh \\
\hline $548.5725-551.8350$ & $\mathrm{C}:$ & $\begin{array}{l}\text { データーを端末じゃなくって:ネッ } \\
\text { トワーク側の方に置いとけば: } \\
\text { (if we place data in the network } \\
\text { rather than on the terminal) }\end{array}$ \\
\hline $551.4175-552.3400$ & E: & j \\
\hline $551.7175-552.1175$ & B: & j \\
\hline $552.4425-556.9450$ & $\mathrm{C}:$ & $\begin{array}{l}\text { 端末落っことしても:ま先ほど:の } \\
\text { ような形で使えないアクセスでき } \\
\text { ないようにしておけば: } \\
\text { (even when we lose your terminal, } \\
\text { if you setup so that other people can } \\
\text { not use, not access) }\end{array}$ \\
\hline $0-554.2625$ & $\mathrm{E}:$ & うんうん \\
\hline $0-554.6675$ & D: & $j h$ \\
\hline $556.2425-557.2450$ & $\mathrm{E}:$ & うんうん \\
\hline $556.7250-557.1150$ & B: & $j h$ \\
\hline $\begin{array}{c}557.5875-558.4275 \\
-\end{array}$ & $\mathrm{C}:$ & $\begin{array}{l}\text { 光つから見れない } \\
\text { (nobody can get data from there) }\end{array}$ \\
\hline $567.2850-567.7400$ & $\mathrm{~B}$ : & あ: \\
\hline $567.6250-567.9725$ & E: & jん \\
\hline $568.0075-568.8775$ & B: & バックアップが \\
\hline $\begin{array}{c}569.0300-569.7200 \\
-\end{array}$ & B: & $\begin{array}{l}\text { あったりとか } \\
\text { (there might be backup) }\end{array}$ \\
\hline $569.7725-570.4025$ & $\mathrm{E}:$ & jん \\
\hline $\begin{array}{c}570.1050-570.7775 \\
-\end{array}$ & $\mathrm{C}:$ & $\begin{array}{l}\text { ええま (W_バツーバックアップ) } \\
\text { (well, backup) }\end{array}$ \\
\hline $570.2625-570.6350$ & D: & j \\
\hline $\begin{array}{c}571.1225-572.4825 \\
-\end{array}$ & B: & $\begin{array}{l}\text { バックアップってことでもないか } \\
\text { (maybe backup is not such a good } \\
\text { idea) }\end{array}$ \\
\hline $571.3425-573.5925$ & $\mathrm{C}:$ & $\begin{array}{l}\text { バックアップだと端末:にデータが } \\
\text { 残つちゃうんで: } \\
\text { (backup leaves data on the terminal) }\end{array}$ \\
\hline $\begin{array}{c}572.6925-573.2025 \\
-\end{array}$ & B: & $\begin{array}{l}\text { 光うか } \\
\text { (right) }\end{array}$ \\
\hline
\end{tabular}

Figure 7: Collaborative elaboration: failure

\begin{tabular}{lr}
\hline \hline Condition & Num \\
\hline Floor with aiduti & 67 \\
Floor with no aiduti & 4 \\
\hline Floor with Collab-Elab. & 29 \\
Floor with no Collab-Elab. & 42 \\
\hline Aiduti speaker initiated Collab-Elab. & 25 \\
non-Aiduti speaker initiated Collab-Elab. & 4 \\
\hline \hline
\end{tabular}

Table 4: Aiduti in Collaborative elaboration

part of non-main speaker participants 'collaborative elaboration.' Collaborative elaboration can be a success or a failure. Figures 6 and 7 show two contrasting examples. In the example in Fig. 6, nonmain speaker participants $C$ and $B$ successfully contribute to the idea proposal by the main speaker $\mathrm{D}$ on combining PC and Skype functionalities, by explicitly pointing out the concrete merit, e.g., free phone call, as a support of the proposal. In the example in Fig. 7, on the other hand, a non-main speaker participant B first tried to make a contribution, the idea of local data backup, to the proposal produced by the main speaker $\mathrm{C}$, storage of data in the network, but gave up after a non-positive response from $\mathrm{C}$ and retracted his additional proposal.

Table 4 shows the relationship between collaborative evaluation and aiduti utterances in a floor. Aiduti utterances were observed in almost every floor. Collaborative elaboration is also rather frequent. It takes place in about $40 \%$ of all floors. Finally, the table shows that participants who perform collaborative evaluation in a floor are likely to produce aiduti utterances in the same floor. This suggests, again, that aiduti utterances from non-main speaker participants of a floor indicate their readiness to make a positive contribution to the joint task, by improving on the proposal currently being discussed.

\section{Discussions}

\section{Frequency of aiduti utterances}

We observed that multi-party conversations contain a high rate $(30 \sim 40 \%)$ of aiduti utterances. a great number of aiduti utterances were produced by the chairperson among all the participants. Saft (2006), based on the analysis of Japanese TV discussion programs, pointed out that chairperson pro- 
duces a large portion of aiduti among all the discussion participants. These findings appear to confirm the idea that aiduti utterances have functions to manage the flow of conversations, and chairpersons exploit these functions in discussion sessions. But, exact conversation flow management function of aiduti may not be unique. According to Saft (2006), the chairperson in the particular TV discussion program uses aiduti to claim their addressee-hood in order to prevent the discussion from free-floating and out of control. In our design conversation data, it appears that the chairperson frequently inserts aiduti in order to encourage other participants to engage in the discussion and to make the session more lively.

\section{Floor structure}

It may not always be a good strategy for everybody to produce aiduti as acknowledgment in a multi-party conversation, since with a lot of hearers it can be a nuisance for the speaker to get too many aiduti in every possible grounding point. It follows that the fact that a certain participant produces aiduti at a certain timing in a multi-party conversation can have significance other than the grounding of the message just produced. It is interesting to note that even though at the level of turn-taking, an aiduti utterance works as a continuer, a turn-yielding signal, at the level of floor, aiduti utterances seem to indicate positive involvement attitude of the participant toward the joint problem solving activity.

\section{Collaborative elaboration}

We observed a number of instances of joint construction of proposals through collaborative elaboration in our design conversation data. It was also observed that in most of the cases of collaborative elaboration, aiduti utterances were accompanied by participants engaging in collaborative elaboration. These facts seem to imply that aiduti utterances both signal and produce among conversation participants an affiliative awareness toward joint construction of the proposal for the problem at hand, through the exchange of readiness signal, among all the group members, toward making positive contributions to the ongoing joint problem solving activity. We believe that these contribution readiness and affiliative awareness are the basis of affective functions of aiduti in Japanese conversations.

\section{Conclusions}

An analysis of aiduti utterances, Japanese backchannels, in a Japanese multi-party design conversation was conducted. It was argued, based on the analysis, that, in addition to the two major functions, signaling acknowledgment and turn-management, aiduti utterances in multi-party conversations are involved in joint construction of design plans through management of the floor structure, and display of participants' readiness to engage in collaborative elaboration of jointly constructed proposals. It was also suggested that these additional functions eventually lead to affective functions of aiduti.

\section{Acknowledgment}

The work reported in this paper was partially supported by Japan Society for the Promotion of Science Grants-in-aid for Scientific Research (B) 18300052.

\section{References}

Futoshi Asano and Jun Ogata. 2006. Detection and separation of speech events in meeting recordings. In Proc. Interspeech, pages 2586-2589.

Nicholas Fay, Simon Garrod, and Jean Carletta. 2000. Group discussion as interactive dialogue or as serial monologue: The influence of group size. Psychological Science, 11(6):487-492.

John Heritage. 2006. An overview of English backchannels. International workshop on cross-cultural and culture-specific aspects of conversational backchannels and feedback, December.

Senko K. Maynard. 1986. On back-channel behavior in Japanese and English casual conversation. Linguistics, 24:1079-1108.

Scott L. Saft. 2006. The moderator in control: Use of names, the particle ne, and response tokens on a Japanese discussion TV program. Research on Language and Social Interaction, 39(2):155-193.

Emanuel A. Schegloff. 1982. Discourse as interactional achievement: some uses of " uh huh" and other things that come between sentences. In Deborah Tannen, editor, Analyzing Discourse, Text, and Talk, pages 71-93. Georgetown University Press. 